\title{
Indigenous uses of plant leaves to treat malaria fever at Omo Forest reserve (OFR) Ogun state, Nigeria.
}

\author{
Adekunle M.F*.
}

\begin{abstract}
.
The indigenous uses of forest plant leaves by the enclave dwellers of Omo forest reserve (OFR) Ogun state, Nigeria were investigated to provide further information on the traditional uses of environmental resources such as the forest in healthcare delivery systems. This is in response to the recent upsurge search for alternative systems of medicare to combat infectious diseases like malaria. Well structured and pretested questionnaire were administered through interview schedules on some randomly selected enclave dwellers of OFR. The questionnaire was made to elicit some information on the species of plants, sources, plant types, form and mode of uses. Twenty (20) plant species mostly trees and shrubs whose leaves were usually extracted to effect cure during malaria attacks were recorded. They are either boiled singly or in combination with other herbs and the extracts are administered orally. The wild forests constituted the major source of these leaves and are either used in fresh or dry forms. However, what is not known is the quantities harvested and the dosage levels. The conclusion was reached that malaria fever must have been a serious health problem in the study area as reported in other African societies looking at the large number of plant species used to effect cure traditionally. Further research is therefore essential into the dosage levels as well as the active ingredients. With the fast disappearance of the African flora especially Nigerians' due largely to deforestation the conservation of these plants become essential and is recommended.
\end{abstract}

Keywords: leaves, Plants, ewe, malaria fever, forest, concoction,

\section{Introduction}

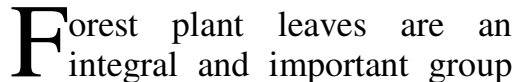
of non wood forest products (NWFP) exploited by rural dwellers and urban poor. Apart from the dietary roles of leaves as a source of protein and other vital minerals to the often starchy staple foods (Martin et al 1998), their medicinal values in the control and management of diverse sicknesses and diseases have been studied (Adekunle 1992, Adebisi 1999).Malaria fever is one of the tropical diseases of socioeconomic importance to which man have been looking for solution for along time. It is the most prevalent of the tropical diseases identified as a threat to more than $40 \%$ of the worlds' population with about 200 to 450 million infections reported annually worldwide (Muriuki 2006). The annual death rate have been recorded at between 1.2 and 2.7.Its area of endemism covers more than 100 topical countries and its control remains a major concern for improved healthcare worldwide. Majority of malaria cases i.e about $90 \%$ are in sub-Saharan Africa and Plasmodium falciparum is the main cause of severe clinical malaria and eventual deaths.

In Nigeria, half of the population record at least an attack yearly with majority of outpatient visits to hospitals and health centers due to malaria attacks (FMOH 2001).According to Oluwalana and Ogunsusi (2007) malaria attack is one the significant factors affecting the income of garri (local food) processors in Odeda local government area, Ogun state , Nigeria. Its control and treatments had been based on traditional knowledge using plant materials such as leaves by the forest dwellers before the advent of modern medicines. Recently, many medical authorities like world health organization (WHO) has come to recognize the place of herbal medicines as a viable alternative in the treatment of malaria infections. Since it mainly afflicts poor populations in the tropics, it attracts scant rewards for

*Department of Forestry and Wildlife Management, University of Agriculture, Abeokuta, Nigeria. 
bioprospecting by big pharmaceutical companies for active molecules that could lead to new drugs. Whereas herbal antimalarial drug development based on traditional knowledge of plant use may hold more promise for developing countries medicines. Hence the relevance of this study which investigated the indigenous use of plant leaves in the treatment of malaria in Omo forest reserve where the disease has been found to be endemic. This will provide a wider data base on the use forest plant parts especially leaves in indigenous healthcare.

\section{The study area}

This study was conducted in Omo forest reserve (OFR) the largest forest reserve in Ogun state of Nigeria. It is situated in Ijebu north and east Local Government Areas of the state with a land area of about 1368 square kilometers. According to Okali and Ola-Adams (1987) OFR is one of the remaining large blocks of high forests in the Nigerian forest estate with an estimated distance of 20 kilometers from the Atlantic Ocean in its southern most part. Historically OFR was created in 1925 and divided into four sections namely: areas $\mathrm{j} 1, \mathrm{j} 3, \mathrm{j} 4$, and $\mathrm{j} 6$. The topography is characterized by an undulating terrain dominated by slopes up to $15 \%$ with elevations reaching 150 meters on a few rocky hills. The vegetation is of a mixed moist semievergreen rainforest type and is drained by river Omo which traverses it and river Oni which forms the eastern and southern boundaries (White 1983, Adekunle 1998). The 460 hectare strict nature reserve (SNR) of man and biosphere (MAB) study is located in the area $\mathrm{j} 4$ section of the reserve. Economic activities such as timber and nontimber products exploitation are going on OFR.Farming is the predominant occupation of the enclave dwellers (Adekunle 1998) and the Gateway Timber Industry is located in the area 44 section of the reserve.

\section{Data collection and analysis}

The main instrument of data collection was a well structured and pretested questionnaire .The questionnaire were 400 in number administered through interview schedules. The respondents were selected using the snowball non probabilistic sampling techniques (McCall and Simmons 1969) in each of areas j1.j3, $\mathrm{j} 4$, and $\mathrm{j} 6$ sections of the study area, that is, 100 respondents in each section. Some of the issues raised in the questionnaire include the local names of plants whose leaves are use to treat malaria, form used, mode of uses and applications. The respondents were made up of farmers, hunters, herbal ware sellers and traditional healers .Taxonomic texts such as Keay (1969) were contacted for the scientific names of the plants. The data were analsed by categorization and presented in form of tables for discussions and conclusions.

\section{Results and discussion.}

The summaries of the plants leaves exploited to treat malaria fever in the study area are shown in Table 1 . According to the table, 20 species made up of 16 families were recorded .The life forms include are trees, 15 species, shrubs, 3 species and herbs, 2 species (Table 2). The leaves of these plants were used singly or in combination with other herbal materials in the fresh or dried forms. The mode of application is mostly oral by drinking the extracts or concoctions. How ever the dosage levels and the quantities harvested at a time are not known. These findings concurred with other studies such as Colfer et al (2006) on the use of forest plants to treat some tropical diseases. They cited the extraction of some pharmaceutical materials such as quinine from Cinchona spp for the treatment of malaria. Some management implications can be deducted from this study, for instance deforestation has been a bane to sustainable utilization of forest resources especially in the tropical countries like Nigeria. For instance majority of the plants are from the wild, if the area is cleared for other purposes, these plants might not be available for use again. Also constant plant defoliation might make regeneration almost near impossible and this is not compatible with the principles of environmental sustainability.

\section{Conclusion}

This study has shown that apart from timber, OFR is a repository of herbal medicines and forest plant leaves has great potentials especially for the treatment and control of malaria fever. It can also be 
concluded that plant leaves are important ingredient in traditional treatment of malaria fever as it featured as a component in many herbal preparations. However some environmental and management problems are imminent such as deforestation and over exploitation. Hence efforts should be made to control the harvesting of these leaves so as not to hamper natural regeneration and forestall environmental degradation. As indigenous knowledge could be a good base for bioprospecting, this potential need to be tapped by incorporating indigenous knowledge into modern systems of medicare. This will go a long way to 'score' goal number six of the millennium development goals (MDGs) which emphasized the need to combat HIV/AIDS, malaria and other diseases by the year 2015 . It is also suggested that the dosage levels of these 'drugs' be investigated as overdose could be lethal to the users. The active ingredients of these leaves should be researched into to develop simple and affordable drugs from them. The cultivation of the plants producing these leaves by the respondents should be encouraged as the natural forests which are a major component of the environment are constantly threatened with extinction. Finally if Nigeria is not to loose his forest estates by 2010 as predicted by Asiodu (2007), environmental resources especially forests should be harvested sustainably and massive afforestation programmes stepped up. A favorable institutional environments and incentives for private investments in trees and forest resources management should be provided by the different levels of government.

\section{References}

Adebisi, L.A. (1999). Biodiversity conservation and ethno botany of selected sacred groves in Osun state, Nigeria. $\mathrm{PhD}$ thesis, Department of Forest Resources Management ,University of Ibadan, Ibadan, Nigeria.(Unpublished) 198p.

Adekunle,M.F. (1992).Traditional medicines and wild plant conservation: a case study of Ogun state,Nigeria. B.Forestry thesis, Department of Forestry and Wildlife Management, University of Agriculture, Abeokuta, Nigeria. (Unpublished) 92p.

Adekunle, M.F. (1998).Survey of nontimber forest products (NTFPS) and their uses in Omo forest reserve.Ogun state, Nigeria. Master of Forestry (MF) thesis, Department of forestry and Wildlife Management, University of Agriculture, Abeokuta, Nigeria. (Unpublished) $158 \mathrm{p}$.
Asiodu, P. (2007).Nigeria risk extinction of forest by 2010. www.thetidenews.com/article .aspx?qrDate=01/30/2007.

Colfer, C.J.P, Sheil, D.Kaimowitz, D, and Kishi, M. (2006).Forests and human health in the tropics. Some important connections.Unasylva 224, vol.57, 2006:3-19. FMOH. (2001). Federal Ministry of Health, Abuja, Nigeria.

Keay, R.W.J. (1989).Trees of Nigeria. (A revised version of Nigerian Trees) Claverondon Press, Oxford .476p

Martin,F.W.,Ruberte,R.M and Meitzner,L.S.(1998).Edible leaves of the tropics. $3^{\text {rd }}$ Edition, ECHO ,North Fort Myers, Florida , USA.(The Overstory 191 www.agroforestry.net ).

McCall,G.J. and Simmons ,J.(1969).Issues in participants observation.In:The practice of social research .Babbie,E.(ed.) Wadsworth Publishing Co. Belmont,Califonia, USA.

Muriuki, J. (2006). Forests as pharmacopoeia: identifying new plant based treatments for malaria. Unasylva 224 vol.57, 2006:24-25.

Okali,D.U.U.and Ola-Adams ,B.A.(1987).Tree population changes in treated rain forest at Omo forest reserve, South western Nigeria.Nig.Jour.of Tropical Ecology.3:291313.

Oluwalana, E.O.A and Ogunsusi, O.O. (2007).Impact of malaria on productivity and coping strategies among small-scale garri processors in Odeda Local Government Area, Ogun, state, Nigeria. African Research Review: 1(2) (August-September 2007) 105115.

White. (1983).The vegetation map of Africa .UNESCO, Paris. 


\section{Table1. Indigenous utilizations of plant leaves for treatment of malaria in Omo forest reserve.Ogun state, Nigeria.}

\begin{tabular}{|c|c|c|c|}
\hline Local name & $\begin{array}{lll}\begin{array}{l}\text { Scientific } \\
\text { family }\end{array} & \text { names } \quad \& \\
\end{array}$ & Forms used & Mode of use \\
\hline Alubosa elewe & $\begin{array}{l}\text { Allium ascalonicum } \\
\text { Alliaceae (herbs) } w\end{array}$ & Fresh\&dry & $\begin{array}{l}\text { Boil with mango,neem } \\
\text { and dry pawpaw leaves as } \\
\text { concoction }\end{array}$ \\
\hline Kaju ,cashew & $\begin{array}{l}\text { Anacardium occidentale } \\
\text { Anacardiaceae (tree) } c\end{array}$ & Fresh\&dry & $\begin{array}{l}\text { Boil singly or with other } \\
\text { herbs and extracts are } \\
\text { taken. }\end{array}$ \\
\hline Mango & $\begin{array}{l}\text { Mangifera indica } \\
\text { Anacardaceae (tree) } c\end{array}$ & Fresh \&dry & $\begin{array}{l}\text { Boil with cashew leaves } \\
\text { and drink the concoction }\end{array}$ \\
\hline Ahun & $\begin{array}{l}\text { Alstonia boonai } \\
\text { Apocynaceae (tree) } w\end{array}$ & fresh & $\begin{array}{l}\text { Boil singly or in } \\
\text { combination with other } \\
\text { herbs }\end{array}$ \\
\hline Oparun & $\begin{array}{l}\text { Babusa vulgaris } \\
\text { Bambusaseae (tree) } w\end{array}$ & Fresh\&dry & Boil with other herbs \\
\hline Ewe akoko & $\begin{array}{l}\text { Newbouldia laevis } \\
\text { Bignonaceae (tree) } w\end{array}$ & Fresh & Boil with other herbs. \\
\hline Abafe & $\begin{array}{l}\text { Piliostigma thonningii } \\
\text { Caesalpinaceae }(\text { shrub) } w\end{array}$ & Fresh & $\begin{array}{l}\text { Boil singly and the } \\
\text { extracts taken as drinks. }\end{array}$ \\
\hline Ibepe,pawpaw & $\begin{array}{l}\text { Carica papaya } \\
\text { Caricaceae (tree) } c\end{array}$ & Dry & $\begin{array}{ll}\text { Boil with } & \text { other } \\
\text { ingredients \&drink. } & \\
\end{array}$ \\
\hline Ewuro,bitterleaf & $\begin{array}{l}\text { Vernonia amygdalina } \\
\text { Compositae }(\text { shrub }) w\end{array}$ & Fresh \& dry & $\begin{array}{l}\text { Squeeze fresh leaves in } \\
\text { water and drink the } \\
\text { extract. Dried leaves can } \\
\text { be cooked with soup. }\end{array}$ \\
\hline Ewe otili & $\begin{array}{l}\text { Cajanus cajan } \\
\text { Leguminoceae }(\text { shrub) c }\end{array}$ & Fresh\&dry & $\begin{array}{l}\text { Boil with other herbs as } \\
\text { concoction }\end{array}$ \\
\hline Ewe owu & $\begin{array}{l}\text { Gossypium barbadens } \\
\text { (shrub) } c \\
\text { Malvaceae }\end{array}$ & fresh & $\begin{array}{l}\text { Squeeze in water and } \\
\text { drink the extracts. }\end{array}$ \\
\hline Ewe dongoyaro,neem & $\begin{array}{l}\text { Azadirachta indica } \\
\text { Meliaceae (tree) } c\end{array}$ & fresh & $\begin{array}{l}\text { 1. Squeeze in water and } \\
\text { drink the extracts. } 2 \text { boil } \\
\text { with other herbs and } \\
\text { drink. }\end{array}$ \\
\hline Ewe emigbegi & $\begin{array}{l}\text { Pseudocedrella kotschyi } \\
\text { Rubiaceae (tree) } w\end{array}$ & Fresh \&dry & $\begin{array}{l}\text { Boil with other herbs and } \\
\text { drink as concotion }\end{array}$ \\
\hline Ewe egbesi & $\begin{array}{l}\text { Nauclea latifolia } \\
\text { Rubiacea (tree) } w\end{array}$ & Fresh\&dry & $\begin{array}{l}\text { Boil with pap water and } \\
\text { drink the extracts }\end{array}$ \\
\hline Ewe osan wewe & $\begin{array}{l}\text { Citrus medica } \\
\text { Rutaceae (tree) } c\end{array}$ & Fresh\&dry & $\begin{array}{l}\text { Cook with other herbs and } \\
\text { drink the conction. }\end{array}$ \\
\hline Ewe aworiwo & $\begin{array}{l}\text { Cola latertia } \\
\text { Sterculiceae (tree)w }\end{array}$ & Fresh\&dry & $\begin{array}{l}\text { Boil with other herbs and } \\
\text { drink the concotion. }\end{array}$ \\
\hline Oruwo & $\begin{array}{l}\text { Morinda lucida } \\
\text { Rubiaceae (tree) } w\end{array}$ & Fresh & $\begin{array}{l}\text { 1. Squeeze the leaves in } \\
\text { water and drink the } \\
\text { extracts.2.cook with other } \\
\text { herbs and drink as } \\
\text { concoction. }\end{array}$ \\
\hline Kulu & $\begin{array}{l}\text { Combretum reticulatum } \\
\text { Combretaceae }(\text { shrub }) w\end{array}$ & Fresh\&dry & $\begin{array}{l}\text { Boil singly and drink the } \\
\text { extract. }\end{array}$ \\
\hline Ewe ose & $\begin{array}{l}\text { Adansonia digitata } \\
\text { Bombacaceae (tree) } w\end{array}$ & Fresh\&dry & $\begin{array}{l}\text { Boil singly and drink the } \\
\text { extract. }\end{array}$ \\
\hline Ewe iseketu & $\begin{array}{l}\text { Sida acuta } \\
\text { Compositae } \\
\text { (Herb) } w\end{array}$ & Fresh & $\begin{array}{l}\text { Boil the fresh leaves in } \\
\text { water and drink }\end{array}$ \\
\hline
\end{tabular}

w-wild c-cultivated

Source-Author's Fieldwork 
Table 2 .Plant life forms

\begin{tabular}{|c|c|}
\hline Life forms & $\begin{array}{c}\text { No of } \\
\text { species }\end{array}$ \\
\hline Trees & 15 \\
\hline Shrubs & 3 \\
\hline Herbs & 2 \\
\hline Total & 20 \\
\hline
\end{tabular}

Source-Author's fieldwork 